\title{
Effects of the Training in Biotechnology on the Attitude, the Behavior and the Knowledge Levels towards Genetically Modified Products
}

\author{
Sevil Ozcan \\ Aydin Health Services Vocational High School, \\ Aydin Adnan Menderes University, Aydin, Turkey \\ E-mail: sozcan@adu.edu.tr
}

\begin{abstract}
The aim of this study was to determine the effects of the biotechnology education on the knowledge, the attitudes and the behaviors of individuals. For this purpose, a survey, consisting of 28 questions in three separate sections, was conducted with 134 students who had already taken a Course on Biotechnology and GMO Products for one semester, and with 130 students who had not taken that course.

When the results of the survey were evaluated, a significant difference was determined in 7 out of the 11 questions prepared to measure the level of knowledge in the topic in favor of the experimental group, who had already taken the course $(\mathrm{p}<.05)$. In the experimental and control groups, the frequency ( $\mathrm{n}: 223$, $84.5 \%$ ) of the idea that health problems, especially the digestive system, will arise due to the consumption of transgenic products was found to be quite high. This negative attitude / thought is statistically significantly higher in the control group than in the experimental group $(\mathrm{p}=000)$. When the answers to the questions about determining the behaviors of wanting to use gene transfer technology were compared, no significant difference was found between the groups $(\mathrm{p}>.05)$.
\end{abstract}

Keywords: Biotechnology training, GM products, Knowledge level, Attitudes, Behaviour

DOI: $10.7176 / \mathrm{JSTR} / 6-07-06$

\section{Introduction}

Cells, which are the building blocks of living things, contain DNA called genomes that determine the properties of living things. Genes corresponding to a region of these DNAs are the most basic genetic unit of living things that determines all features from external appearance to metabolic activities and to what diseases are resistant or prone to them. Thanks to recombinant DNA methods such as genetic engineering, biotechnology and PCR, scientists have succeeded in isolating genes, making changes in genes, and transferring these genes to the creatures they acquire, or to another species. The new organism, which will be created by transferring a gene that has been altered or isolated using one of the different gene transfer methods, is called as a Genetically Modified Organism (GMO), or a Transgenic Organism. Initially, GMO products were offered to the service of humanity, considering that it would be a solution to hunger on earth. Today, GMOs have found themselves in many fields, especially in agriculture and health. With the use of GMO technologies in agriculture, it is aimed to obtain species that are resistant to environmental conditions such as cold, salinity, drought, more productive, and resistant to diseases caused by insects and viruses. Similarly, GMO technology is used in order to increase the meat and milk yield of animals or to minimize operating costs by providing different features such as chicken without feathers. On the other hand, human studies are mostly in the form of treatment and repair of genetic diseases. With this method, healthy copies of genes that cause hereditary diseases are transferred or healthy genes are placed in bacteria and products such as insulin are synthesized and used in treatment (Bayrac et al., 2007).

Although Biotechnology is used in many fields, as we have mentioned above, there are serious concerns in communities against products produced with GMO technology. While biologists and environmentalists have ecological concerns, such as the disappearance of genetic diversity or the emergence of more resistant pest species over time; healthcare providers are concerned about the combination of foreign DNAs taken with nutrients into human DNA and transferred to the next generations in the form of mutations or their toxic and allergic effects (Ergin et al., 2008). 
On the other hand, these advances in biotechnology have become one of the important scientific and technological developments that affect the daily life of societies (Pardo, Midden \& Miller, 2002). Individuals are forced into the decision-making process regarding consuming these transgenic products or foods produced as a result of biotechnological developments (Hanegan \& Bigler, 2009). Knowledge and attitude are also effective factors in individuals' decision to use a product or not. Verdurme and Viaene (2003) stated that the general attitude and knowledge of consumers about GMO foods are effective in the formation of this perception and that consumers' perception of risk and benefit is effective against these products in the consumer attitude towards GMO foods. Since the production of GMO products, many researches have been carried out on this subject, especially to measure the knowledge and attitude of the societies. In addition, in many countries, in the education system, new subjects have been added to the curricula of courses such as biology in this field or they have been associated with the curriculum in the form of new courses. In fact, new departments or teaching programs such as Genetic Engineering have been opened as a sub-branch of biology (Hanegan \& Bigler 2009; Steele \& Aubusson 2004). According to the information obtained from studies investigating the level of knowledge of individuals related to GMOs, it has been observed that students have insufficient and incorrect information on these issues and access the information they have from more media (Dawson, 2007; Prokop et al., 2007; Usak et al., 2009 Özcan, 2010; Özcan \& Altıntaş, 2011). In order to determine students 'attitudes towards biotechnology applications at different levels, researchers examined factors such as acceptability, trust, benefit and risk, and reported that individuals' attitudes differ according to the types of GMO practices (Dawson \& Schibeci, 2003; Klop \& Severiens, 2007; Dawson, 2007; Prokop et al., 2007; Private, Erdogan, Uşak \& Prokop, 2009).

According to the behavioural intent model, the intention or desire to purchase a transgenic food product is determined by the attitude and control perception towards purchasing the product. Similarly, consumers' attitudes towards purchasing GMO food products are significantly affected depending on their perception of the properties of these products and on their belief in the consequences of consuming these products (Bredahl, 2000).

Accordingly, the aim of this study is to determine whether the attitudes and behaviours of health technician candidates studying at Adnan Menderes University towards genetically modified or transgenic products change depending on the level of education and knowledge received. The problem statement of the research is the question of "Do the attitudes and behaviours of Health Technician Candidates towards GMO Products change depending on the education and on the level of knowledge given?" Sub problems of this study are as follows:

1.Does the level of knowledge of candidates of health technicians about GMO products differ depending on education?

2.Do the thoughts and behaviours of the health technician candidates on the effects of GMO products on human health differ depending on the education and knowledge level received?

3.Do the opinions and behaviours of the health technician candidates on the effects of GMO products on human health differ according to the gender of the candidates?

The Importance of the Research: Health technicians who will serve as intermediate staff in the field of health in the future are the personnel who will contact the patients and their relatives in many different fields and health institutions before the doctor. This means that they can guide and influence societies with their knowledge of health and health influencing factors and their attitudes, thoughts and behaviours in this regard. As with any subject, if these candidates are given correct and adequate training on biotechnology and GMO products, future health technicians will be effective in terms of public health, in raising awareness, informing individuals, and forming correct attitudes and behaviours.

\section{Material and Method}

In this study, causal and structural relationships between product knowledge, risk perception and behaviors of consumers were analyzed by linear structural equation modeling analysis. The research was carried out in AYDIN ADNAN MENDERES UNIVERSITY (ADU), AYDIN HEALTH SERVICES VOCATIONAL HIGH SCHOOL (AHSVHS) in 2017-2019 academic years.

\subsection{Universe and Sampling}

This study, which was planned as a cross-sectional study, was carried out with 264 students studying in AHSVHS in the 2017-2019 academic years. The registered students (n: 2500) constituted the universe of the study and the 264 students who had chosen the elective Biotechnology and GMO Products course

64 I P a g e

www.iiste.org 
made the sampling group. 134 students $(50.7 \%)$ who had taken and completed the course in the fall semester constituted the Experimental Group (EG), and 130 (49.3\%) students who had chosen the course in the spring semester and have not yet taken the course made the Control Group (CG). 169 (64\%) of the students who participated in the study were females, $93(35.2 \%)$ were males and $2(0.8 \%)$ did not answer this question. The students were given 8 different programs (Anesthesia, Environmental Health, Dialysis, Physiotherapy, First and Emergency Aid, Medical Imaging, Medical Laboratory Techniques and Medical Secretariat Technicians).

\subsection{Research Model}

In this study, a random research design with post-test control group, which is one of the experimental models, was used. In this model, the dependent variable is applied to two different groups and the data (scores) of the groups related to the relevant variable are compared (Karasar, 2010). The participants of this study were entirely coincidentally composed of students who had chosen the extra-departmental elective "Biotechnology and GMO Products" course in their 2017-2018 and 2018-2019 academic years. Students who had received 15 weeks of training at the end of the fall semester comprised the EG. While the test was applied to this group at the end of the semester, the same test was applied to the students who had chosen the course in the spring semester (CG) at the beginning of the semester before any training.

\subsection{Data Collection Tool}

For this purpose, a questionnaire, consisting of three-parts and of closed-ended questions to be answered as yes or no and prepared by the researcher, was used. The first part is aimed at measuring the level of knowledge of the participants. In this section, there are 11 different expressions including the situations that we use / encounter in our daily lives and were asked as "Which ones are produced by GMO technology?" In the second part, the question of "Which health problems can GMO products cause?" was asked the participants by giving 10 different diseases and other alternatives to determine the opinions and attitudes of them about the effects of the use of GMO products on human health. In the third part, in order to determine the behaviors of using Biotechnology and GMO technology in some cases, 8 different genetic features and other alternatives were given and asked as "If it were possible by using GMO technology, which of the following genes would you like to be transferred to the zygote that will be your child?"

\subsection{Evaluation of The Data}

The data obtained from the surveys were analyzed with the SPSS package program. In the questions in the first part, the correct answers were entered as 1 and the wrong answers as 0. The highest Success Score (SS) is 11 . In the second and third sections, the marked items are entered as 1 , and the items not marked are entered as 0 .

In the first stage, Skewness and Kurtosis tests were performed to examine whether the data show normal distribution by applying normality test. In normality tests, the values were Skewness $=0.444$ and Kurtosis $=0.343$. Since these values are between $-0.5-0.5$, the results are symmetrical and show a normal distribution. For the data obtained, the values were delineated as (f) for Frequency, (\%) for percentage, $(\overline{\mathrm{x}})$ for mean and (SD) for standard deviation, using chi-square and t-test and to determine the level of significance, comparisons, based on gender and between the Experimental and Control Groups (EG= Students having taken Biotechnology and GMO courses; $C G=$ Students not having taken the courses) were made. The reliability coefficient of the questionnaire is $\alpha=0.67$.

\section{Results}

\subsection{Knowledge level:}

Achievement points were obtained by gathering the correct answers given by the students who participated in the survey. When the distribution of these success scores was analyzed separately and together for the experimental and control groups, it was determined that each of them showed a normal distribution [Fig 1].

According to this, the mean of the $\mathrm{CG}$ is $\overline{\mathrm{x}}=4.57(\mathrm{SD}= \pm 1.323)$, Mod= $4(\mathrm{n}: 41 ; 31.5 \%)(\mathrm{Fig} 1)$ and the mean of the $\mathrm{EG}$ is $\overline{\mathrm{x}}=5.51$ ( \pm 1.818$)$, Mod= 5 (n: 33; $24.6 \%$ ) (Fig1). The mean of the total of the groups was determined as $\overline{\mathrm{x}}=5.05(\mathrm{SD} \pm 1.66), \mathrm{Mod}=5$ (n: 68, $25.8 \%)$ and it displays a normal distribution [Fig 2].

The correct answers of the Experimental and Control Groups regarding with the question of "which of the given definitions are the products produced by GMO technology?" are given in Table 1. When the results are examined, there is a statistically significant difference in favor of EG in 7 questions $\left(2^{\text {nd }}, 3^{\text {rd }}\right.$,

65 | P a g e

www.iiste.org 
$4^{\text {th }}, 5^{\text {th }}, 7^{\text {th }}$ and $9^{\text {th }}$ questions), while there is a significant difference in favor of CG in two questions ( $1^{\text {st }}$ and $6^{\text {th }}$ questions) $(\mathrm{p}<.05)$. There was no difference between groups in one question ( $8^{\text {th }}$ question) [Table $1]$.

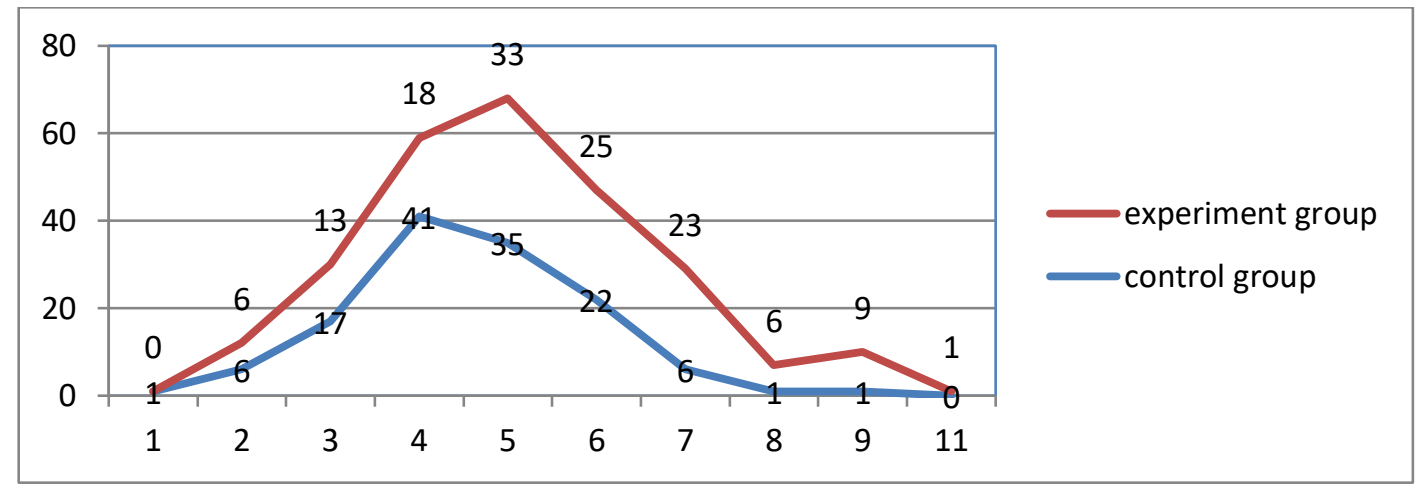

Figure 1. Distribution of the Correct Answers of the EG and CG Participants in the First Part

The statement of "insect resistant gene taken from bacteria was transferred to some plants" was answered correctly by $75.0 \%$ of the students (n: 198) and this is the best known of the products produced with GMO technology. The statement of "Hormone use for plant development" is the most misunderstood situation that was answered correctly only by $8.7 \%$ of the students (n: 23). A significant portion of the students, such as $91.3 \%$, think that the use of hormones for growth or for parthenocarpic fruit formation is GMO.

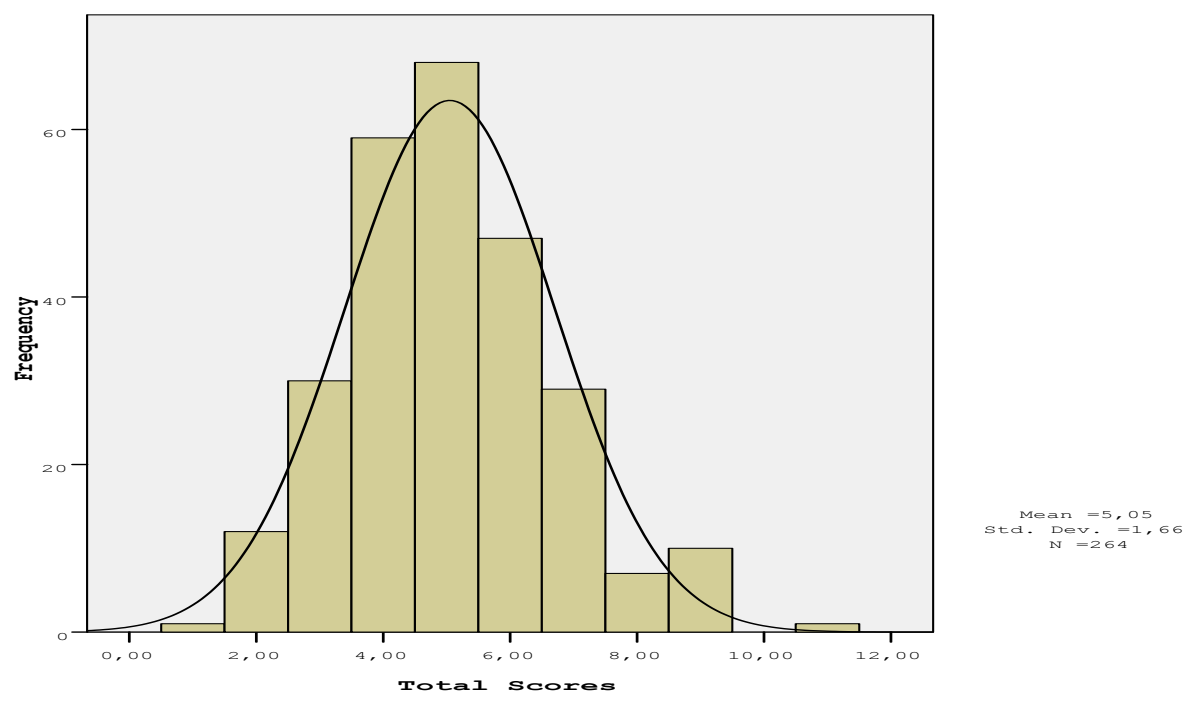

Figure 2. SS Distribution of the Answers of the Students to the Knowledge Questions in the First Part Related with the Products Produced Using GM Technology

\subsection{Students' thoughts/attitudes on the issue that GMO products might cause health problems in} humans:

When the answers given to this question were compared with the chi-square test, it was determined that health problems such as "Stomach-Intestinal Cancers", "Disability-stillbirth" and "Infertility" were significantly more marked by CG (p <, 05) [Table 2]. When the data were compared with the t-test, "Digestive system problems", "Ur formation" and "Rapid aging" options were marked more by CG, while "Allergy" option was found to be significantly more marked by EG than CG $(p<.05)$.

On the other hand, it was determined that all participants had the opinion, on particularly nutrition, that GMO products could lead to "Digestive system problems" (n: 223, $84.5 \%$ ), to "Obesity" (n: 213, 80.7 $\%$ ) and to Gastrointestinal cancers" (n: 190) and in other words, it was observed that they had negative attitudes [Table 2]. The least probable health problems by students are "Ur formation" (n: 98, 37.1\%) and "Mutation" (n: 152, 57.6\%). 
Table 1. Distribution of the Correct Answers Belonging to EG and CG Regarding the Products Produced with GMO Technology.

\begin{tabular}{|c|c|c|c|c|}
\hline $\begin{array}{l}\text { Which of the following are the products } \\
\text { produced with GMO technology? }\end{array}$ & $\begin{array}{l}\text { EG Correct } \\
\qquad \mathrm{N}(\%)\end{array}$ & $\begin{array}{l}\text { CG Correct } \\
\mathrm{N}(\%)\end{array}$ & $\begin{array}{l}\text { Total Correct } \\
\mathrm{N}(\%)\end{array}$ & $\mathrm{p}$ \\
\hline $\begin{array}{l}\text { 1. Plants grown by using insecticides during } \\
\text { their growth to prevent insects }\end{array}$ & $49(36.6)$ & $80(61.5)$ & $129(48.9)$ & $.00^{* *}$ \\
\hline $\begin{array}{l}\text { 2. Plants grown with hormones so that they } \\
\text { become bigger }\end{array}$ & $19(14.2)$ & $4(3.1)$ & $23(8.7)$ & $.00^{*}$ \\
\hline $\begin{array}{l}\text { 3. Plants to which "insect resistant gene, } \\
\text { which some bacteria possess, has been } \\
\text { transferred to prevent insects }\end{array}$ & $111(82.8)$ & $87(66.9)$ & $198(75.0)$ & $.00^{*}$ \\
\hline $\begin{array}{l}\text { 4. Bacteria whose insect resistant gene was } \\
\text { taken to transfer to plants }\end{array}$ & $95(70.9)$ & $56(43.1)$ & $151(57.2)$ & $.00^{*}$ \\
\hline $\begin{array}{l}\text { 5. Wild tomato carrying the gene taken from } \\
\text { another type of tomato }\end{array}$ & $110(82.1)$ & $79(60.8)$ & 189 (71.6) & $.00^{*}$ \\
\hline 6. Bacteria carrying insect resistant gene & $60(44.8)$ & 98 (75.4) & $158(59.8)$ & $.00^{* *}$ \\
\hline 7. Bacteria producing human insulin & $90(67.2)$ & $23(17.7)$ & $113(42.8)$ & $.00^{*}$ \\
\hline $\begin{array}{l}\text { 8. Fruit grown in various shaped containers } \\
\text { during their growth and having different views } \\
\text { other than normal }\end{array}$ & $54(40.3)$ & $52(40.0)$ & $106(40.2)$ & $>.05$ \\
\hline 9. Chickens fed with GMO feeds & $38(28.4)$ & $22(16.9)$ & $60(22.7)$ & $.02^{*}$ \\
\hline $\begin{array}{l}\text { 10. Animals such as cattle, sheep, etc. that were } \\
\text { born by artificial insemination }\end{array}$ & $53(39.6)$ & $73(56.2)$ & $126(47.7)$ & $.00^{* * *}$ \\
\hline $\begin{array}{l}\text { 11. Tobacco plant carrying rabies vaccine } \\
\text { factor }\end{array}$ & $60(44.8)$ & $20(15.4)$ & $80(30.3)$ & $.00^{*}$ \\
\hline
\end{tabular}

*experimental group better/bigger than control group; **control group better/bigger than experimental group

According to these results, it can be said that the students in the CG are more likely of the opinion that the possibility of the GMO products to lead to health problems in humans is high and that they displayed more negative attitudes [Table 2].

When the answers given about health problems were compared by gender, it was seen that females saw GMO products riskier in terms of health and had a more negative attitude than males. There was a statistically significant difference in the responses of women, especially in the subjects of "Infertility" (n: 133, 77.8\%) and "Obesity" (n: 144, 84.2\%) [Table 3].

\subsection{Students' wishes/behaviours towards the use of "Gene transfer" method for the features that they} want their children have:

In this section, 8 different genetic features about which people complain saying "I wish it were different" or they have aesthetic interventions made in order to change them, and they were asked which genes they would like to be transferred to their child's genotype with GMO technology. When the answers were evaluated, it was seen that the vast majority of students showed more positive behaviours in contrast to the second part and stated that they could use this technology to transfer many features [Table 4]. 
Table 2. Health Problems That Experiment and Control Groups Believe GMO Products Might Cause.

\begin{tabular}{|c|c|c|c|c|c|}
\hline \multirow[b]{2}{*}{ Health Problems } & \multirow{2}{*}{$\begin{array}{c}\text { EG Yes } \\
\mathrm{N}(\%)\end{array}$} & \multirow{2}{*}{$\begin{array}{c}\text { CG Yes } \\
\text { N }(\%)\end{array}$} & \multirow{2}{*}{$\begin{array}{c}\text { Total Yes } \\
\text { N }(\%)\end{array}$} & \multicolumn{2}{|c|}{$\mathrm{P}$} \\
\hline & & & & $\begin{array}{c}\text { Chi- } \\
\text { Square }\end{array}$ & t-test \\
\hline 1. Allergy & $104(77.6)$ & $92(70.8)$ & $196(74.2)$ & $>.05$ & $.012^{*}$ \\
\hline 2. Stomach-Intestine Cancers & $85(63.4)$ & $105(80.8)$ & $190(72.0)$ & $.001^{* *}$ & $.000^{* *}$ \\
\hline 3. Digestive System Problems & $108(80.6)$ & $115(88.5)$ & $223(84.5)$ & $>.05$ & $.000^{* * *}$ \\
\hline 4. Mutation & $76(56.7)$ & $76(58.5)$ & $152(57.6)$ & $>.05$ & $>.05$ \\
\hline 5. Ur Formation & $45(33.6)$ & $53(40.8)$ & $98(37.1)$ & $>.05$ & $.020^{* *}$ \\
\hline 6. Skin Discomfort & $94(70.1)$ & $96(73.8)$ & $190(72.0)$ & $>.05$ & $>.05$ \\
\hline 7. Cripple- Still Birth & $57(42.5)$ & $73(56.2)$ & $130(49.2)$ & $.018^{* *}$ & $>.05$ \\
\hline 8. Infertility & $87(64.9)$ & $107(82.3)$ & $194(73.5)$ & $.001^{* *}$ & $.000^{* * *}$ \\
\hline 9. Fast Aging & $69(51.5)$ & $77(59.2)$ & $146(55.3)$ & $>.05$ & $.038^{* * *}$ \\
\hline 10. Obesity & $106(79.1)$ & $107(82.3)$ & $213(80.7)$ & $>.05$ & $>.05$ \\
\hline
\end{tabular}

The most desired phenotypes are "Tallness" (n: 200, 76.3\%) and "Replacing the owned ill gene with the healthy one" (n: 183, 69.8\%). The least desired genetic character was "Curly hair" (n: 97, 37.0\%).

Table 3. Distribution of the Health Problems According to Gender That Students Think GMO Products Might. Cause.

\begin{tabular}{|l|l|l|l|l|}
\hline & \multirow{2}{*}{ Health Problems } & Female Yes & Male Yes & \multicolumn{2}{|c|}{$\mathrm{P}$} \\
\cline { 5 - 6 } & $\mathrm{N}(\%)$ & $\mathrm{N}(\%)$ & Chi-Square & t-test \\
\hline 1. Allergy & $130(76.0)$ & $66(71.0)$ & $>.05$ & $>.05$ \\
\hline 2. Stomach-Intestine Cancers & $129(75.4)$ & $61(65.6)$ & $>.05$ & $.002^{*}$ \\
\hline 3. Digestive System & $148(86.5)$ & $75(80.6)$ & $>.05$ & $.014^{*}$ \\
\hline 4. Mutation & $96(56.1)$ & $56(60.2)$ & $>.05$ & $>.05$ \\
\hline 5. Ur Formation & $65(38.0)$ & $33(35.5)$ & $>.05$ & $>.05$ \\
\hline 6. Skin Discomfort & $124(72.5)$ & $66(71.0)$ & $>.05$ & $>.05$ \\
\hline 7. Cripple-Still Birth & $90(52.6)$ & $40(43.0)$ & $>.05$ & $>.05$ \\
\hline 8. Infertility & $133(77.8)$ & $61(65.5)$ & $.02^{*}$ & $.000^{*}$ \\
\hline 9. Fast Aging & $93(54.4)$ & $53(57.0)$ & $>.05$ & $>.05$ \\
\hline 10. Obesity & $144(84.2)$ & $69(74.2)$ & $.03^{*}$ & $.000^{*}$ \\
\hline
\end{tabular}

*female bigger than male

In general, approximately $3 / 4$ of the participants stated that they may want the gene transfer method to be used on the zygote that will constitute their children. This situation is higher especially in the Control Group compared to the Experimental Group [Table 4]. The statistical difference between experimental and control groups is related only to the genes related with "Small Nose" and "Different Skin Color" (p $<.05)$. 
Table 4. Behaviour of Experimental and Control Groups Regarding the Transfer of Some Genetic Features to Their Children by Gene Transfer Method.

\begin{tabular}{|l|c|c|c|l|l|}
\hline & EG Yes & CG Yes & Total Yes & \multicolumn{2}{|c|}{ P } \\
\cline { 5 - 6 } Desired phenotypes & $\mathrm{N}(\%)$ & $\mathrm{N}(\%)$ & $\mathrm{N}(\%)$ & Chi-square & t-test \\
\hline 1. Tallness & $100(75.8)$ & $100(76.9)$ & $200(76.3)$ & $>.05$ & $>.05$ \\
\hline 2. Blue Eye Colour & $75(56.8)$ & $72(55.4)$ & $147(55.6)$ & $>.05$ & $>.05$ \\
\hline 3. Curly Hair & $48(36.4)$ & $49(37.7)$ & $97(37.0)$ & $>.05$ & $>.05$ \\
\hline 4. No Body Hair Growth & $82(62.1)$ & $94(72.3)$ & $176(67.2)$ & $>.05$ & $.001^{*}$ \\
\hline 5. Small Nose & $84(63.6)$ & $96(73.8)$ & $180(68.7)$ & $.049^{*}$ & $.000^{*}$ \\
\hline 6. Light/ Dark Skin Colour & $77(58.3)$ & $91(70.0)$ & $168(64.1)$ & $.033^{*}$ & $.002^{*}$ \\
\hline 7. Less Fat Cells & $77(58.3)$ & $70(53.8)$ & $147(56.1)$ & $>.05$ & $>.05$ \\
\hline $\begin{array}{l}\text { 8. The Transfer of the healthy gene } \\
\text { instead of the ill one I have }\end{array}$ & $92(69.7)$ & $91(70.0)$ & $183(69.8)$ & $>.05$ & $>.05$ \\
\hline
\end{tabular}

*control group bigger than experimental group

In the second part, although female students have more negative thoughts about the fact that GM crops cause health problems, it is determined that they want the gene transfer method more to be used on the zygote that will create their children [Ttable 5]. Especially "Curly Hair", "No Body Hair Growth" and "Small Nose" phenotypes are marked significantly higher in females than in males. While the most desired feature in females was "No Body Hair Growth" (n: 128, 75.3\%), it was seen that "Tallness" (n: $73,79.3 \%$ ) in men.

Table 5. Distribution of the Behaviors of the Students Regarding the Transfer of Some Genetic Features to Their Children according to Gender.

\begin{tabular}{|l|l|l|l|l|}
\hline & \multirow{2}{*}{ Desired phenotypes } & Female Yes & Male Yes & \multicolumn{2}{|c|}{$\mathrm{P}$} \\
\cline { 4 - 6 } & $\mathrm{N}(\%)$ & $\mathrm{N}(\%)$ & $\begin{array}{c}\text { Chi- } \\
\text { square }\end{array}$ & t-test \\
\hline 1. Tallness & $127(74.7)$ & $73(79.3)$ & $>.05$ & $>.05$ \\
\hline 2. Blue Eye Color & $94(55.3)$ & $53(57.6)$ & $>.05$ & $>.05$ \\
\hline 3. Curly Hair & $70(41.2)$ & $27(29.3)$ & $.039^{*}$ & $.000^{*}$ \\
\hline 4. No Body Hair Growth & $128(75.3)$ & $48(52.2)$ & $.000^{*}$ & $.000^{*}$ \\
\hline 5. Small Nose & $125(73.5)$ & $55(59.8)$ & $.016^{*}$ & $.000^{*}$ \\
\hline 6. Ligth/ Dark Skin Color & $112(65.9)$ & $56(60.9)$ & $>.05$ & $>.05$ \\
\hline 7. Less Fat Cells & $95(55.9)$ & $52(56.5)$ & $>.05$ & $>.05$ \\
\hline $\begin{array}{l}\text { 8. The Transfer of the healthy gene instead of the } \\
\text { ill one I have }\end{array}$ & $125(73.5)$ & $58(63.0)$ & $>.05$ & $.001^{*}$ \\
\hline
\end{tabular}

*female bigger than male

\section{Discussion and Result}

Rapid developments in Biotechnology, especially in the 2000s, enabled advances in the science of genetics. In this way, the genetic structures of living things were changed, making it possible to give the plants and animals the desired features. In fact, biotechnology has started to be used in many areas, not only limited to living things but from the pharmaceutical, medical, veterinary, agricultural and food industries associated with human and other creatures, to chemistry, environmental protection and the production of different devices and prostheses for human health. However, while these products appear 
in almost every field in our daily life, on the other hand, different segments of the communities have started to react differently to these products.

As a result of day-to-day biotechnology applications and the studies conducted on GMO products, it is reported that there are differences in people's knowledge, attitude and behavior in many countries (Zechendorf, 1994; Chen \& Raffan, 1999; Joyce \& Farenga, 1999; Sjöberg, 2004; Bánáti, D., \& Lakner, Z. 2006; Dawson, 2007; Klop \& Severiens, 2007; Črne-Hladnık et al., 2009; Özel et al., 2009).

Considering the results of previous studies, it is reported that the knowledge individuals have about GMO products and biotechnology is generally obtained from the media (Özcan, 2010; Özcan \& Altıntaş, 2014). Issues such as human / animal cloning or gene transfer, which attract the attention of the societies, are also of interest to the media, and various information are provided on these topics whose scientific validity can be discussed from different perspectives. From this point, it has been found out that it is important to provide biotechnology education in schools (Hanegan \& Bigler 2009; Steele \& Aubusson 2004). Biotechnology-related topics are placed in primary, high school and higher education curricula in many countries (Steele \& Aubusson 2004). Likewise, in our study, similar to the results of previous studies, it was concluded that health technician students did not have sufficient knowledge about GMO products, and that even the beliefs that hormone use and the animals fed on GMO feeds were also GMOs. However, when EG and CG results were compared, it was seen that the level of knowledge increased significantly with the training provided.

In some of the studies conducted, it has been reported that there is a significant relationship between knowledge and attitude and more positive attitude emerges as the level of knowledge increases (Young, 1998; Weaver, 2002; Di Enno and Hilton, 2005). In this study, it was determined that negative attitudes towards GMO products were higher in CG. In other words, as the level of knowledge increased (in EG), the idea that transgenic products would cause health problems was found to have decreased. In the studies carried out, it was reported that female students have a more negative attitude towards GMO products (Turkmen \& Darcin, 2007; Özcan, 2010; Özcan \& Altıntaş, 2014). Similarly, in this study, it is one of the conclusions that the idea/worry of transgenic products will cause health problems was stronger in female students compared to male students.

Bilen and Özel (2012) stated that students consider some of the biotechnology applications to be useful, while others consider the applications to be risky and that GMO products should be used for the benefit of technology or people. Verdurme and Viaene (2003) emphasized that the leading brands give more confidence, and that consumers are more willing to buy branded GMO food products than general / ordinary GMO food products. Medical applications of biotechnological products are accepted easier and more than other applications such as food (Zechendorf, 1994). In the third part, when the answers given about the requests to use this technology were evaluated, it was determined that an important part of both EG and CG, such as 70-75\%, expressed that many phenotypes could be used to be transferred to the genotype of their child. Although there was a statistically significant difference between the experimental and control groups in cases of knowledge level and the idea of causing health problems, no significant difference was observed between the groups in terms of behavior. In their study, Saez et al. (2008) reported that when evaluating the biotechnological applications of the students, they considered their personal needs and the benefit that the product would provide, and these results also support our results.

\section{Suggestions}

Purchasing is related to the attitudes that individuals have about that product, and one of the factors affecting attitude is the level of knowledge. While increasing number and variety of transgenic products are offered to consumers day by day, their acceptance by consumers and elimination of concerns can only be achieved through education.

We believe that, in addition to the students who receive health education, similar studies should be carried out with students studying in different disciplines such as social sciences, engineering and economics, and comparing the results will help to reveal the opinion structure of the society and what needs to be done.

\section{References}

Bánáti, D., \& Lakner, Z. (2006). Knowledge and acceptance of genetically modified foodstuffs in hungary. Journal of food and nutrition research 45 (2): 62-65. [Online] Available: file:///C:/Users/Dell/Downloads/jfnr06-2-p062-068-banati.pdf

Bayraç, A. T., Baloğlu, M. C., Kalemtaş, G., Kavas, M. (2007). Genetiği Değiştirilmiş Organizmalar. Ankara: ODTÜ Geliştirme Vakfı Yayıncılık, 34-42.

70 | P a g e

www.iiste.org 
Bilen, K., \& Özel, M. (2012). Gifted students' knowledge of and attitudes toward biotechnology. Necatibey Faculty of Education Electronic Journal of Science and Mathematics Education 6 (2): 135-152. [Online] Available: http://www. nef.balikesir. edu.tr/ dergi/makaleler /yayinda /13/EFMED_FBE201.pdf

Bredahl, L. (2002), Determination of Consumer Attitudes and Purchase Intentions with Regard to Genetically Modified Foods: Result of a Cross-national Survey, working paper No.69. Center for Market Surveillance Research and Strategy fort he Food Sector, The Aarhus School of Business, Denmark.

Chen, S. Y., \& Raffan, J. (1999). Biotechnology: Student's knowledge and attitudes in the UK and Taiwan. Journal of Biological Education, 34(1): 17-23.

Črne-Hladnık, H., Peklaj, C., Košmelj, K., Hladnık, A., \& Javornık, B. (2009). Assessment of Slovene secondary school students' attitudes to biotechnology in terms of usefulness, moral acceptability and risk perception. Public Understanding of Science, 18(6): 747758.

Dawson, V. (2007). An exploration of high school (12-17 year old) students' understandings of, and attitudes towards biotechnology processes. Research in Science Education, 39: 59-73.

Dawson, V., \& Schibeci, R. (2003). Western Australian high school students' understanding of biotechnology. International Journal of Biological Education, 38 (1): 7-12. doi: $10.1080 / 00219266.2003 .9655889$

Di Enno, C. M., \& Hilton, S. C. (2005). High school students' knowledge, attitudes, and levels of enjoyment of an environmental education unit on non-native plants. Journal of Environmental Education 37: 13-25.

Ergin, I., Gürsoy, Ş. T., Öcek, Z. A., Çiçeklioğlu, M. (2008). Sağlık meslek yüksekokulu öğrencilerinin genetiği değiştirilmiş organizmalara dair bilgi, tutum ve davranışları. TAF Prev Med Bull; 7: 503-508.

Hanegan, N. L., \& Bigler, A. (2009). Infusing authentic inquiry into biotechnology. Journal of Science Education and Technology, 18(5): 393-401.

Joyce, B. A., \& Farenga, S. J. (1999). Informal science experience, attitudes, future interest in science, and gender of high-ability students: An exploratory study. School Science and Mathematics, 99: 431-437.

Karasar, N. (2000). Bilimsel araştırma yöntemi-kavramlar, İlkeler, Teknikler. (10th Ed.). Nobel Yayınevi. Ankara.

Klop, T., \& Severiens, S. (2007). An exploration of attitudes towards modern biotechnology: a study among Dutch secondary school students. International Journal of Science Education, 29 (5): 663679.

Özcan, S. (2010). Description Knowledge, Attitude and Behavior of Teacher Candidates towards GDO's Products Which are to be Product of Biotechnology. $6^{\text {th }}$ Nanoscience and Nanotechnology Conference, V.1 (1), p. 202, İzmir. [Online] Available: http://nanotr6. iyte.edu.tr /english $/$ docs/conference-book/Oral\%20Presentation-Theme\%20N.pdf

Özcan, S., \& Altıntas, G. (2014). Description of the knowledge, attitude and behaviours of candidate teachers regarding genetically modified products. Multidisciplinary Perspectives on Education, 119-126. [Online] Available: https://books. google.com. tr/books?hl= tr\&lr=\&id= YcoxBwAA QBAJ\&oi= fnd\&pg= PA119\&dq=related:WEEYSme32esJ:scholar.google.com/\&ots=1_ezw-7j8 $\mathrm{J} \& \operatorname{sig}=\mathrm{E} 47 \mathrm{qN} 3 \mathrm{ako}$ 48QEK7NNSiwAnqMo-4\&redir_esc=y\#v=onepage \&q\&f=false 
Özel, M., Erdoğan, M., Uşak, M., \& Prokop, P. (2009). Lise öğrencilerinin biyoteknoloji uygulamalarına yönelik bilgileri ve tutumları. Kuram ve Uygulamada Ĕ̈itim Bilimleri, 9(1): 297328.

Pardo, R., Midden, C., \& Miller, J. (2002). Attitudes toward biotechnology in the European Union. Journal of Biotechnology, 98(1): 9-24.

Prokop, P., Lešková, A., Kubiatko, M., \& Diran, C. (2007). Slovakian students' knowledge and attitudes toward biotechnology. International Journal of Science Education, 29(7): 895-907.

Saez, M. J., Nino, A.G. \& Carretero, A. (2008). Matching society values: Students' view of biotechnology. International Journal of Science Education 30,167-183.

Sjöberg, L. (2004). Gene Technology in the Eyes of the Public and Experts. Moral Opinions, Attitudes and Risk Perceptions. (SSE/EFI Working Paper Series in Business Administration No. 2004:7).

Steele, F., \& Aubusson, P. (2004). The challenge in teaching biotechnology. Research in Science Education, 34(4): 365-387. The European Initiative for Biotechnology Education. [Online] Available: http://www.eibe.info.

Turkmen, L., \& Darcin, E. (2007). A comparative study of Turkish elementary and science education major students' knowledge levels at the popular biotechnological issues. International Journal of environmental \& Science Education 2 (4): 125-131.

Uşak, M., Erdogan, M., Prokop, P., \& Özel, M. (2009). High school and university students' knowledge and attitudes regarding biotechnology: A Turkish experience. Biochemistry and Molecular Biology Education, 37(2): 123-130.

Verdurme, A., \& Viaene, J. (2003). Exploring and modelling consumer attitudes towards genetically modified food. Qualitative Market Research 6 (2): 95-110. [Online] Available: https://www.researchgate.net/publication/240260180_Exploring_and_modelling_consumer_attit udes_towards_genetically_modified_food

Weaver, A. A. (2002). Determinants of environmental attitudes. International Journal of Sociology, 32 (1): 77-108.

Young, T. (1998). Student Teachers' Attitudes towards Science (STATS). Evaluation \& Research in Education, 12 (2): 96-111. doi: 10.1080/09500799808666934

Zechendorf, B. (1994). What the public thinks about biotechnology. Bio/Technology, 12: 870-871. 